\title{
RADIOCARBON DATE FREQUENCY AS AN INDEX OF INTENSITY OF PALEOLITHIC OCCUPATION OF SIBERIA: DID HUMANS REACT PREDICTABLY TO CLIMATE OSCILLATIONS?
}

\author{
Stuart J Fiedel \\ Louis Berger Group, 203 East Cary Street, Suite 100, Richmond, Virginia 23219, USA. Corresponding author. \\ Email: sfiedel@louisberger.com.
}

\section{Yaroslav V Kuzmin}

Pacific Institute of Geography, Far Eastern Branch of the Russian Academy of Sciences, Radio St. 7, Vladivostok 690041, Russia. Email: ykuzmin@tig.dvo.ru.

\begin{abstract}
Upper Paleolithic humans occupied southern Siberia by about 43,000-38,000 BP ( ${ }^{14} \mathrm{C}$ yr), and afterward continued to live there despite the very cold climate. If climatic conditions limited expansion of the colonizing population in northern Siberia, the Paleolithic ecumene should have contracted during the coldest episodes within the last $40,000 \mathrm{yr}$, and fewer ${ }^{14} \mathrm{C}$-dated sites should be known from those periods. In fact, the human population seems to have remained stable or even expanded during cold periods. Comparison of calibrated ${ }^{14} \mathrm{C}$ dates for Siberian occupations with Greenland ice cores fails to demonstrate a simple correlation between climatic fluctuations and the dynamics of human colonization and persistence in Siberia between about 36,000 and 12,000 BP. Cold climate does not appear to have posed any significant challenge to humans in Siberia in the Late Pleistocene, and a supposed Last Glacial Maximum "hiatus" in population dynamics seems illusory.
\end{abstract}

\section{INTRODUCTION}

The correlation between intensity of human colonization or occupation of particular regions and climatic fluctuations throughout the last $45,000{ }^{14} \mathrm{C}$ yr has been the subject of recent research, carried out mainly in Europe (e.g. Gamble et al. 2004, 2005). Several attempts also have been undertaken recently to discern patterns of a possible connection between the dynamics of human occupation and climate during the Late Pleistocene in Siberia (e.g. Goebel 2002; Dolukhanov et al. 2002; Graf 2005; Kuzmin and Keates 2005; Surovell et al. 2005). In this paper, we ask, does the varying intensity of Upper Paleolithic occupation of northern Eurasia correlate with climatic fluctuations?

As Behrensmeyer (2006:478) recently observed, “...climate was only one of many factors affecting human evolution; biological processes including genetic innovation, interspecies competition, and dispersal ability also could have played defining roles. Rather than a simple story of global climate drumbeat and evolutionary response, more informative and exciting revelations about the 7-millionyear development of hominin morphology, behavior, and culture will likely come from detailing the prolonged tension between local ecosystems and global climate change. This is also a strikingly relevant theme for the future of our species." In the case of the Paleolithic human occupation of northern Eurasia, we must consider the possible complexities of adaptive responses of both ecosystems and human sociocultural systems to climatic changes. We should not simply assume that humans responded directly to colder temperatures as a negative stress factor by means of population reduction, contraction of settlement area, or outright abandonment of the entire region. We must test the existing data without presuppositions. In this paper, we address the issue of possible human susceptibility to fluctuating climatic conditions at the end of the Pleistocene, using Siberia and the Russian Far East as the key regions.

Discussions of human evolution are generally written by academics who, unlike Arctic natives such as the Eskimo and Chukchi, find extreme cold uncomfortable and unnatural. It is now well established that hominins evolved in subtropical environments in eastern Africa, and that modern humans 
(Homo sapiens sapiens) emigrated from there to more northern regions where cultural innovations including protective clothing and shelter and controlled use of fire were essential for survival. It is generally assumed that Neanderthals, having occupied glacial Europe for several hundred thousand years before the arrival of modern humans around 43,000-41,000 cal BP (Mellars 2006; Weninger and Jöris 2006), had adapted both physically and culturally to cold climate. Yet, they evidently were out-competed in their familiar environment by intrusive "moderns." This replacement scenario involves some complicated permutations. On the one hand, the superior mental and behavioral flexibility, complex social structure, and logistical and planning capabilities of modern humans are thought to have permitted their expansion into far northern zones (such as the East European Plain) that were vacant because Neanderthals lacked the cultural equipment to thrive there (Hoffecker 2002; Mellars 2006). However, the same authors suppose that the moderns could only displace Neanderthals from central and western parts of Europe when the latter were undercut by an abrupt cold oscillation (Greenland Stadial 9 or 10). It seems paradoxical that a plunge into colder climate would have advantaged tropical-adapted intruders over local hominins with longstanding adaptations to near-glacial environments. Perhaps we have grossly misjudged the relative challenges and opportunities that cold climates posed to anatomically and behaviorally modern humans.

Humans with Upper Paleolithic technology appear to have occupied the southern part of Siberia at a remarkably early date, about $43,000-38,000{ }^{14} \mathrm{C}$ yr ago (hereafter BP) (see reviews: Derevianko $2001,2005)$. This colonization occurred about the same time as the appearance of the Upper Paleolithic in the Eastern European Plain, e.g. at Kostenki (Anikovich et al. 2007). Settlements persisted for millennia despite the fact that throughout the Late Pleistocene, Siberia was even colder than it is today (e.g. Velichko 1984). In spite of the obvious early human adaptation to very cold conditions, several archaeologists discern evidence of abandonment of northern regions for a millennium or more at the peak of the Last Glacial Maximum (LGM) (generally assumed to be the period when regional temperatures fell to a minimum). For example, Hoffecker (2002:195) observed a hiatus in the central part of the Eastern European Plain from $~ 20,000$ to $~ 18,000$ BP. Dolukhanov and his coauthors (Dolukhanov and Shukurov 2004; Dolukhanov et al. 2002:598; Dolukhanov et al. 2005: 1128, Figure 2) also infer a sparse human population in Siberia at the LGM, which they define as about 19,000-18,000 BP. Similarly, Goebel (2002) sees abandonment of much of Siberia at about $19,000-18,000$ BP. But do the data really support this inference?

\section{METHODS AND MATERIALS}

Numerical analysis of ${ }^{14} \mathrm{C}$ date series for the Upper Paleolithic of northern Eurasia has become a common approach (e.g. Housley et al. 1997; Bocquet-Appel and Demars 2000; Davies 2001; Dolukhanov et al. 2001; van Andel and Davies 2003; Gamble et al. 2005). However, a major methodological problem for such studies is how to combine the individual ${ }^{14} \mathrm{C}$ dates produced at each site into frequencies of occupation with consequent calibration or comparison (sensu van der Plicht 2000) of occupations, for the purpose of examining the relationship of cumulative frequencies of human occupation to proxy records of climate fluctuations, particularly the Greenland ice cores. Several approaches have been used (see review: Kuzmin and Keates 2005:775-7).

Before proceeding to further describe specific aspects of our analysis, we must acknowledge both the limitations of the available data set and the potential flaws in our own assumptions and analytical procedures. We have assumed that varying relative quantities of human habitation episodes over time-for which ${ }^{14} \mathrm{C}$ dates per millennium are a proxy-primarily reflect fluctuations in the size and geographic extent of the human population (i.e. "occupation intensity"). We recognize that other factors might create biases that could distort this record; these include the following: 
1. Problems of preservation or visibility of sites. Sites in river valleys may have been destroyed during periods of increased fluvial erosion, or deeply buried by alluvial sediments. Similarly, sites could have been deeply buried by loess during periods of eolian deposition. It is not clear whether these processes would tend to obscure more human occupations during stadial or interstadial episodes.

2. Over the passage of time since deposition, organic materials are less likely to survive, so there are less potential samples for dating from the earliest millennia of human occupation. Furthermore, as one approaches the effective limit of radiocarbon dating at around 40,000 BP, the potential effects of contamination and counting error increase, so dates earlier than $\sim 30,000 \mathrm{BP}$ become both unavoidably less precise and possibly inaccurate. While recognizing these problems, we emphasize that our focus here is primarily on interpretation of dates more recent than 28,000 BP.

3. Research priorities and funding limitations can affect the record. Some sites considered relevant to particular issues - e.g. initial appearance of moderns, demise of Neanderthals, or origin of microblade industries - may have been the focus of more intensive ${ }^{14} \mathrm{C}$ dating programs than other sites. Researchers may have relied on artifact typology or geologic/climatic data for dating of less critical sites.

4. Dates may be artificially concentrated within particular sites or sub-regions. Continuity of occupation in these locations might obscure contemporaneous abandonment of other areas. We have attempted to counteract this bias by combining multiple dates for single stratified components into "occupations."

5. Some dates are clearly inaccurate and unacceptable. This is sometimes apparent because of their incongruity within stratified sequences. When multiple dates over a very wide temporal range occur within a single stratified context, some systematic protocol must be adopted to either include or eliminate the outliers.

We recognize that any or all of these factors could substantially distort the record. In light of these undeniable complications, one has the choice of ignoring the cumulative ${ }^{14} \mathrm{C}$ record from Siberia as too problematic for any meaningful interpretation, or searching for evident patterns in the imperfect data and testing hypotheses that might explain those patterns. We have chosen the latter course.

As an example of how we have treated sites with multiple ${ }^{14} \mathrm{C}$ dates (factor 4 , see above), we can use data from the well-known site of Mal'ta in Eastern Siberia (Table 1). The wide variation of ${ }^{14} \mathrm{C}$ values in the site's main component, layer 8, is evident. For some intervals, about 20,000-21,000 BP and $21,000-22,000 \mathrm{BP}$, many more ${ }^{14} \mathrm{C}$ values were obtained, as compared with the approximately 19,000-20,000 BP interval (Figure 1). If one were to take these records at face value, an obvious distortion of occupation frequency would result due to the numerous ${ }^{14} \mathrm{C}$ dates produced at this particular site for the same cultural component. Following Kuzmin and Keates (2005), we do not use such "raw" ${ }^{14} \mathrm{C}$ records. Instead, we combine dates into $1000-{ }^{14} \mathrm{C}$ yr intervals, so-called "occupation episodes" (Figure 1), in order to make the data set smoother and eliminate the distorting effect of multiple ${ }^{14} \mathrm{C}$ dates for the same cultural layer. This procedure may be contrasted with an alternative approach to the averaging of dates. The mean age of the series is about $21,040 \pm 240 \mathrm{BP}$, and with $\pm 2 \sigma$ it is $21,520-20,560 \mathrm{BP}$. In this case, Graf (2005) would exclude several values beyond this time interval, about $21,700-21,600 \mathrm{BP}$ and about $20,340-19,990 \mathrm{BP}$, and use only the "averaged" ${ }^{14} \mathrm{C}$ value of $\sim 21,040 \mathrm{BP}$ (Figure 1). It is obvious that averaging significantly simplifies the initial information about the ${ }^{14} \mathrm{C}$ age of the site. In this case, only 1 brief "occupation" of the site, at $21,040 \mathrm{BP}$, will be detected, while in reality it may have been occupied repeatedly over a longer period, about 19,900-21,700 BP (see discussion in Kuzmin and Keates 2005:779-80). It can be very difficult to 
distinguish single occupations, true "living floors," from "palimpsests" created by conflation of multiple episodes (Binford 1982). Fine-grained analysis (e.g. studies of refitting lithics) may yield evidence of real contemporaneity of activity areas within a community, but few Siberian sites have ever been subjected to such close scrutiny.

Table $1{ }^{14} \mathrm{C}$ records for Mal'ta site, Eastern Siberia (after Lipnina et al. 2001).

\begin{tabular}{llll}
\hline Site, cultural layer & ${ }^{14} \mathrm{C}$ date, BP & Lab code and $\mathrm{nr}$ & Material \\
\hline Mal'ta, layer 8 & $21,700 \pm 160$ & OxA-6191 & Animal bone \\
Mal'ta, layer 8 & $21,600 \pm 170$ & GIN-8475 & Animal bone \\
Mal'ta, layer 8 & $21,600 \pm 200$ & GIN-7708 & Animal bone \\
Mal'ta, layer 8 & $21,340 \pm 240$ & OxA-6193 & Animal bone \\
Mal'ta, layer 8 & $21,300 \pm 110$ & GIN-7702 & Animal bone \\
Mal'ta, layer 8 & $21,300 \pm 300$ & GIN-7704 & Animal bone \\
Mal'ta, layer 8 & $21,100 \pm 150$ & GIN-7703 & Animal bone \\
Mal'ta, layer 8 & $21,000 \pm 140$ & GIN-7706 & Animal bone \\
Mal'ta, layer 8 & $20,900 \pm 200$ & GIN-4367 & Animal bone \\
Mal'ta, layer 8 & $20,800 \pm 140$ & GIN-7710 & Animal bone \\
Mal'ta, layer 8 & $20,700 \pm 150$ & GIN-7709 & Animal bone \\
Mal'ta, layer 8 & $20,340 \pm 320$ & OxA-6192 & Animal bone \\
Mal'ta, layer 8 & $19,900 \pm 800$ & GIN-7705 & Animal bone \\
Mean of 13 dates & $21,040 \pm 240$ & & \\
\hline
\end{tabular}

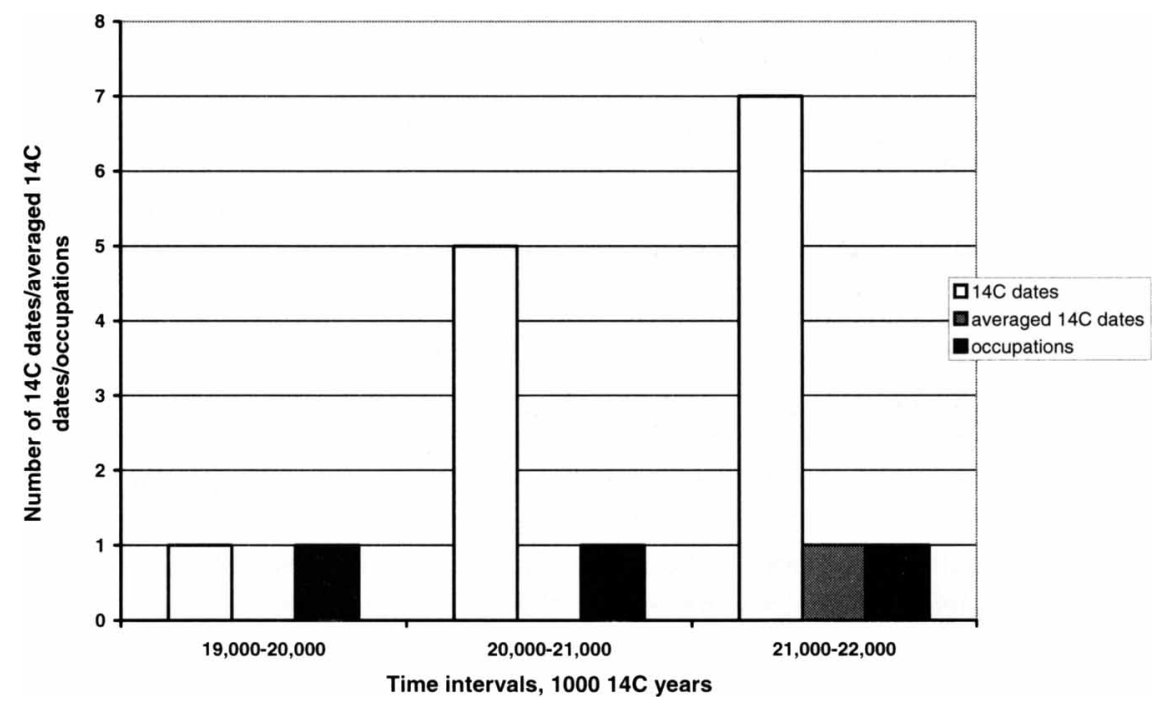

Figure 1 The counting of occupation frequencies at the Mal'ta site

For this paper, we combined ${ }^{14} \mathrm{C}$ dates available for the Siberian Paleolithic as of late 2004 into "occupations" within intervals of $1000{ }^{14} \mathrm{C}$ yr (see Vasil'ev et al. 2002; Kuzmin and Keates 2005), and calculated the average ${ }^{14} \mathrm{C}$ age of each occupation (see Appendix). Because there are very few ${ }^{14} \mathrm{C}$ dates for the Siberian Paleolithic earlier than $~ 36,000$ BP (Kuzmin and Keates 2005), only ${ }^{14} \mathrm{C}$ ages of about $12,000-35,800 \mathrm{BP}$ were used. In total, 387 individual ${ }^{14} \mathrm{C}$ dates, mainly from the Upper Paleolithic sites with a few final Middle Paleolithic complexes, were combined into 249 occupations (Figure 2). 


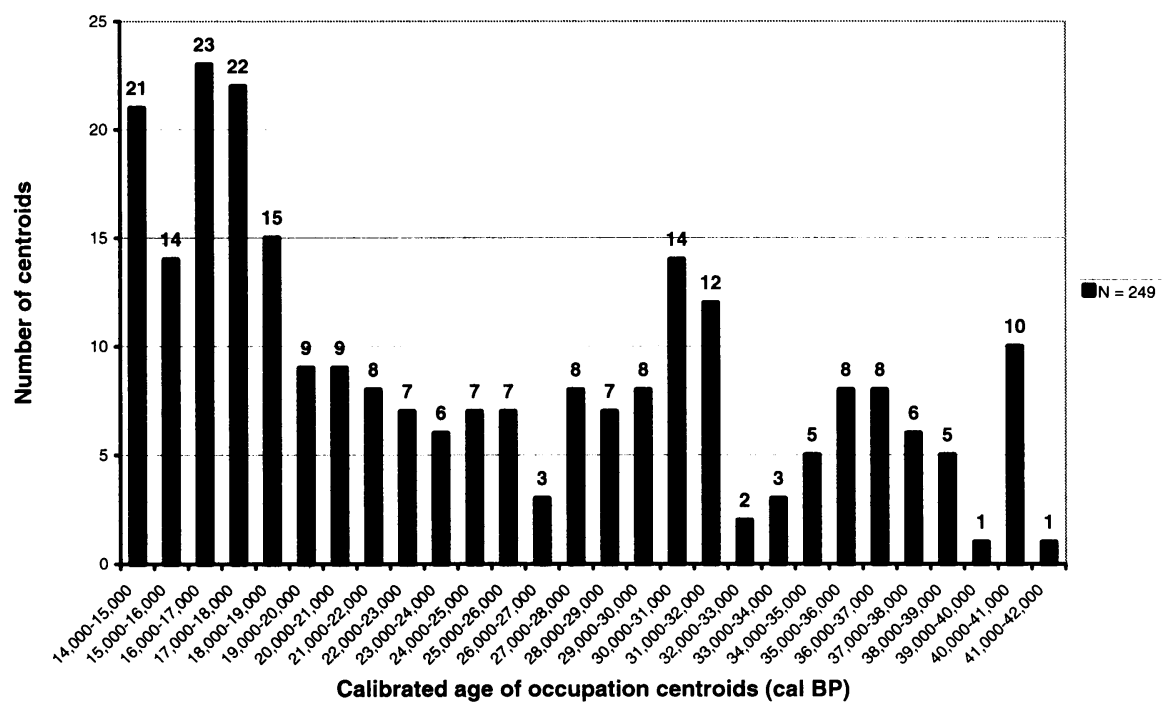

Figure 2 Frequencies of calibrated ages of occupation "centroids" for the Siberian Paleolithic, about $14,000-42,000 \mathrm{cal} \mathrm{BP}$.

After calculating the average ${ }^{14} \mathrm{C}$ values for each occupation episode within the period about $12,000-35,800 \mathrm{BP}$, the calendar ages (hereafter cal BP) of mean points or "centroids" were determined using 1 of 2 calibration software packages: 1) CALIB 4.4.2 (Stuiver and Reimer 1993) for dates as far back as 19,540 BP (Ust-Kova site, lower component; see Appendix); and 2) CalPal (Weninger and Jöris 2004; Weninger et al. 2005) for older ages. Because the frequency of "centroids" is the main aim of our study, we determined the calendar ages of centroids by calibrating them with a conventional standard deviation (hereafter s.d.) of $\pm 100 \mathrm{yr}$, and calculated the median calendar age of each centroid with \pm 2 s.d.

The frequencies of calendar age centroids were counted (Table 2, Figure 2). A similar approach to plotting the calibrated median ages of individual ${ }^{14} \mathrm{C}$ values was recently employed by Gamble et al. (2005:197).

Table 2 Frequencies of "calibrated" occupations of the Siberian Paleolithic, 14,000-42,000 cal BP.

\begin{tabular}{lllc}
\hline Calendar ages, cal BP & $\mathrm{Nr}$ of occupations & Calendar ages, cal BP & Nr of occupations \\
\hline $14,000-15,000$ & 21 & $28,000-29,000$ & 7 \\
$15,000-16,000$ & 14 & $29,000-30,000$ & 8 \\
$16,000-17,000$ & 23 & $30,000-31,000$ & 14 \\
$17,000-18,000$ & 22 & $31,000-32,000$ & 12 \\
$18,000-19,000$ & 15 & $32,000-33,000$ & 2 \\
$19,000-20,000$ & 9 & $33,000-34,000$ & 3 \\
$20,000-21,000$ & 9 & $34,000-35,000$ & 5 \\
$21,000-22,000$ & 8 & $35,000-36,000$ & 8 \\
$22,000-23,000$ & 7 & $36,000-37,000$ & 8 \\
$23,000-24,000$ & 6 & $37,000-38,000$ & 6 \\
$24,000-25,000$ & 7 & $38,000-39,000$ & 5 \\
$25,000-26,000$ & 7 & $39,000-40,000$ & 1 \\
$26,000-27,000$ & 3 & $40,000-41,000$ & 10 \\
$27,000-28,000$ & 8 & $41,000-42,000$ & 1 \\
& & Total occupations & 249 \\
\hline
\end{tabular}


We recognize that calendar ages beyond about 23,000 cal BP currently must be considered only approximate, with uncertainties up to several thousand years (see van der Plicht et al. 2004). Therefore, all conclusions for the time span older than about 23,000-25,000 cal BP are tentative. Nevertheless, recent studies indicate an emerging consensus of marine core-, ice-core-, and speleothemderived timescales (e.g. Shackleton et al. 2004; Southon 2004; Weninger et al. 2005; Weninger and Jöris 2006), so it is unlikely that our chronological framework, which is based primarily upon the GISP2 ice core, will prove to be grossly inaccurate.

For comparison of the occupational data to climate fluctuations, we relied primarily upon the GISP2 ice-core record (e.g. Johnsen et al. 2001) of the climatic conditions in the Northern Hemisphere between about 14,000-42,000 cal BP. Both the Hulu Cave speleothems and new data from the NGRIP ice core (North Greenland Ice Core Project Members 2004) indicate that the GISP2 timescale for this period is more accurate than the alternative GRIP chronology. We also referred to some regional high-resolution climatic archives located either in Siberia itself (the Lake Baikal sediments [Prokopenko et al. 2001; Boës et al. 2005]) or relatively nearby (the Hulu Cave stalagmites in southern China [Wang et al. 2001]).

\section{RESULTS AND DISCUSSION}

\section{Human-Climate Relationship in the Paleolithic of Siberia}

Comparison of climatic fluctuations against the frequency of human occupation (Figure 3) reveals no direct correlation between climate and intensity of occupation. For example, at the so-called "Last Glacial Maximum" (LGM), about 24,000 cal BP, when the climate was very cold and dry, the population in Siberia apparently did not decrease. It remained comparatively stable from roughly 26,000 cal BP until about 19,000 cal BP, and increased sharply afterwards (Figure 3).

Early paleoclimatic models for Siberia (e.g. Kind 1974) postulated 2 broad subdivisions, the (relatively) warm Karginsky or Karginian "Interglacial" (properly termed an interstadial) around 50,000-24,000 BP, and the cold Sartan "Glacial" (i.e. stadial), about 24,000-10,000 BP, each with minor fluctuations. However, integration of recent data requires a much more complicated paleoclimate reconstruction. Rather than the simple dichotomy of warm Karginsky and cold Sartan periods, it is likely that the Siberian Late Pleistocene climate from about 50,000-11,000 cal BP displayed the same "sawtooth" pattern of abrupt warm and cold oscillations that has been recognized in the Greenland ice cores, GRIP and GISP2 (e.g. Johnsen et al. 2001). The precise synchronicity of East Asian climate oscillations with the GISP2 sequence is shown by the Hulu Cave stalagmite record of the East Asian monsoon from China (Wang et al. 2001). Periods of maximum dust accumulation in the GISP2 core (notably between 26,180 and 23,340 cal BP) also correlate directly with cold, dry, windy periods in Central Asia; the dust in the ice has been traced to Mongolia and northern China (Biscaye et al. 1997). Although interpretation of specifically Siberian data from Lake Baikal sediments is complicated, magnetic susceptibility data from the Continent Ridge core indicate a rough correlation with GISP2 events; the coldest period occurs about 26,000-23,000 cal BP (Boës et al. 2005). Prokopenko et al. (2001:67) recognize abrupt erosional events in Lake Baikal that are "confidently correlated to the intervals of Heinrich layers in the North Atlantic." These events indicate "a surprisingly strong climatic teleconnection of the remote mid-continent Baikal location with the Dansgaard-Oeschger events and the Bond cycles in the North Atlantic region" (Prokopenko et al. 2001:67).

Basically, Dansgaard-Oeschger (D-O) events are warm episodes and Heinrich $(\mathrm{H})$ events are cold ones. The D-O marine events are coeval with atmospheric events recorded in the Greenland ice as 
relatively warm interstadials; Heinrich events equate to abrupt cold (stadial) episodes in the ice (Greenland Stadials, GS). The latest correlation of ocean (coral U/Th dates) and ice records for the period 20,000-50,000 BP, with calibrated ${ }^{14} \mathrm{C}$ dates for D-O marine events, has been presented by Shackleton et al. (2004) (Table 3).

Table 3 The sequence of warm (Dansgaard-Oeschger, D-O) and cold (Heinrich, H; Greenland Stadials, GS) climatic events in northern Eurasia for the period about 12,000-37,000 BP (after Shackleton et al. 2004).

\begin{tabular}{clllll}
\hline D-O event & $\begin{array}{l}\text { Calendar age, } \\
\text { cal BP }\end{array}$ & $\begin{array}{l}{ }^{14} \mathrm{C} \text { age, } \\
\text { BP }\end{array}$ & $\begin{array}{l}\text { Cold event } \\
\text { (H/GS) }\end{array}$ & $\begin{array}{l}\text { Calendar age, } \\
\text { cal BP }\end{array}$ & $\begin{array}{l}{ }^{14} \text { C age, } \\
\text { BP }\end{array}$ \\
\hline 1 & 14,700 & 12,500 & H1 & 16,000 & 13,000 \\
2 & 23,700 & 19,600 & H2 & 24,000 & 20,000 \\
3 & 24,450 & GS4 & 29,500 & 25,000 \\
4 & 25,000 & 25,300 & H3 (GS5) & 31,000 & 27,000 \\
5 & 30,100 & 28,500 & GS6 & 33,000 & 28,000 \\
6 & 33,400 & 29,500 & GS7 & 34,000 & 29,500 \\
7 & 34,600 & 31,900 & GS8 & 36,000 & 32,000 \\
8 & 36,300 & 33,800 & H4 & 40,000 & 34,000 \\
9 & 39,000 & 35,500 & GS9 [?] & 41,500 & 36,000 \\
10 & 40,800 & 36,100 & GS10 [?] & 43,000 & 37,000 \\
\hline
\end{tabular}

Since 1976, when the Last Glacial Maximum was defined by the CLIMAP group, a date of 18,000 BP has been conventionally assigned to the LGM, and climate stability between 14,000 and 24,000 BP has been assumed (Mix et al. 2001). LGM refers specifically to the moment when the proportion of the planet's water locked into ice sheets was greatest in relation to liquid water in the ocean. The latter is measured by sea level, so the LGM is the moment of lowest recorded sea level in the Late Pleistocene. Although "LGM" is often used as shorthand for extreme cold, Greenland ice-core proxies for temperature (oxygen isotope ratios in snow layers, which reflect sea surface temperatures in the North Atlantic) show that the coldest temperatures and greatest ice sheet volumes were not precisely synchronous. Ice sheet extent in Europe at any given time was actually influenced by a complex interplay of precipitation and temperature (Rinterknecht et al. 2006). Based upon minimum sea levels of about 130-135 m below present level off the northern coast of Australia, Yokoyama et al. (2000) dated the LGM as the period from 22,000 to 19,000 cal BP (16,000 BP). A sharp rise in sea level marks the end of the LGM in this record. Citing both marine and ice-core data, the EPILOG group defined the LGM chronozone as the interval from 23,000 to 19,000 cal BP (i.e. 19,500 16,100 BP) (Mix et al. 2001). Recently, Peltier and Fairbanks (2006) have interpreted sea-level data from Barbados as indicating an earlier minimum and thus, the LGM beginning at around $26,000 \mathrm{cal}$ BP. 
If we set aside the rather arbitrary definition of LGM and instead examine the GISP2 ice-core record of oxygen isotope ratios directly as an index of cold temperatures in the far north (Figure 3), we find that the coldest episodes in the last $40,000 \mathrm{yr}$ occurred at $\sim 36,000$ cal BP (corresponding to $\sim 32,000$ $\mathrm{BP}) ; \sim 33,000$ cal BP ( 28,000 BP); 32,000-29,000 cal BP ( 28,000-25,000 BP); and $\sim 24,000 \mathrm{cal}$ $\mathrm{BP}(\sim 20,000 \mathrm{BP})$ (Table 3). At the time equivalent to $18,000-19,000 \mathrm{BP}$, or $21,000-22,000 \mathrm{cal} \mathrm{BP}$ (Hughen et al. 2004)-the conventionally defined LGM-it was quite cold, but not measurably colder than at $\sim 12,500 \mathrm{cal}$ BP or $\sim 16,000 \mathrm{cal} \mathrm{BP}$, and not nearly as cold as at $\sim 24,000$ cal BP or at $\sim 30,000$ cal BP. In fact, the longest period of sustained cold with no warming oscillation is the $4000 \mathrm{yr}$ from $\sim 27,500$ to 23,500 cal BP (about 24,000-20,000 BP). If cold climate was the limiting factor on expansion of human settlement in Siberia, these are the periods when we should anticipate the greatest contraction of occupied area and the fewest dated sites and components.

However, this expectation is not confirmed by our data set and its analysis. A particularly interesting and rather complicated portion of the sequence is that between 33,000 and 30,000 cal BP. Our data indicate very sparse occupation at 33,000-32,000 cal BP, followed by a surge in dates (and inferred occupation intensity) at $32,000 \mathrm{cal}$ BP continuing to $30,000 \mathrm{cal} \mathrm{BP}$. This is the period of the brief occupation of the Yana RHS site in the high Arctic (about $\left.71^{\circ} \mathrm{N}\right)$. A series of published dates seems to put the occupation around 27,000 BP, or 31,000 cal BP (Pitulko et al. 2004), but a date closer to $\sim 28,000 \mathrm{BP}(32,500 \mathrm{cal} \mathrm{BP})$ is now preferred (Pitulko 2006). Pollen and other paleoenvironmental data indicate a relatively warm, interstadial climate at the time of occupation. The original date of $\sim 27,000$ BP would make Yana RHS coeval with the H3 cold event, which is framed by D-O episode 4 at $\sim 25,300$ BP (30,000 cal BP) and D-O episode 5 at $\sim 28,500$ BP $(33,400$ cal BP) (Shackleton et al. 2004). Given the pollen record from the site, however, it seems that the occupation more likely occurred toward the end of the relatively warm D-O episode 5. It is intriguing to observe that the date of Yana RHS corresponds precisely to the maximum frequency of dated horse and mammoth bones from the Laptev Sea area (Hubberten et al. 2004: Figure 6). Perhaps human hunters were responding to a maximum availability of prey animals in far northern Eurasia at that time.

Our data show a sharp increase in occupation frequency beginning about 19,000 cal BP $(16,000 \mathrm{BP})$. This is well in advance of the abrupt Bølling-Allerød warming at $14,700 \mathrm{cal} \mathrm{BP}$. The period from 22,000 to 18,000 cal BP appears only slightly warmer than 27,000 to 24,000 cal BP in GISP2. However, Greenland climate of that period may not have been representative of wider patterns. Lagerklint and Wright (1999) point to several Northern Hemisphere records of warming beginning around $18,000 \mathrm{cal}$ BP. Antarctic ice cores show a steady warming trend into the Holocene that begins about 20,000 cal BP (Bender et al. 1999). Cosmogenic nuclide dating of moraines indicates that glacial recession in mid-latitudes of both the Northern and Southern hemispheres may have begun in some areas about 19,000 cal BP, but was certainly well underway globally by $\sim 17,400$ cal BP. This recession is ascribed to rising summer temperatures (Schaefer et al. 2006). Orbitally calculated summer insolation for $60^{\circ} \mathrm{N}$ starts to increase at about 20,000 cal BP (Berger and Loutre 1991). This might have had appreciable effects on plant cover, thus increasing forage for the herbivores upon which Siberian hunters were dependent. The record of Laptev Sea fauna dates is not precisely synchronous with the Siberian occupation dates, but it is grossly similar; the former series has an extreme low point at 17,500-15,000 BP, but this is followed by a steep (threefold) increase at 15,000-12,500 BP (Hubberten et al. 2004: Figure 6). Again, this increase precedes the BøllingAllerød warming $(12,500 \mathrm{BP}$, or $14,700 \mathrm{cal} \mathrm{BP})$. It is reasonable on this basis to hypothesize that increasing availability of prey animals may have been the proximate cause of the growth and expansion of Siberian Upper Paleolithic populations. 


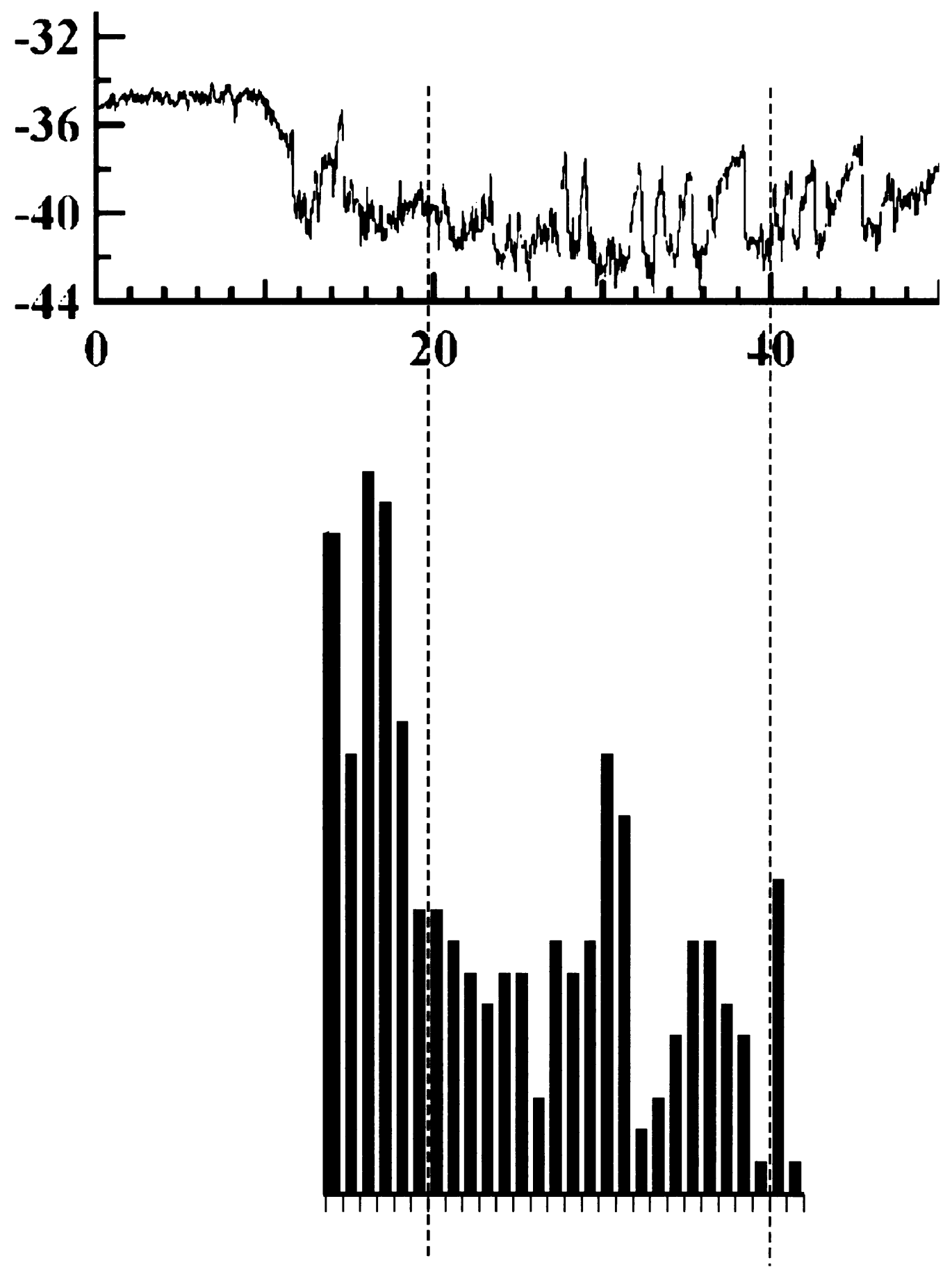

Figure 3 Comparison of the occupation frequencies for the Paleolithic of Siberia (below; see also Figure 2) and the GISP2 ice-core records (above; after Johnsen et al. 2001). Vertical axis above is $\delta^{18} \mathrm{O}(\%)$; horizontal axis is ice-core age (kyr BP). 


\section{Combining ${ }^{14} \mathrm{C}$ Dates into Occupations: Progress and Problems}

The research protocols used to detect regional-scale patterns of human occupation on the basis of ${ }^{14} \mathrm{C}$ dates must confront and somehow resolve 2 methodological complications: 1) If listed and counted separately, multiple ${ }^{14} \mathrm{C}$ values from the same site or cultural component may distort the "real" signal of human occupation (Figure 1). Weighted disproportionately against single dates obtained for sites/components of other periods, the multiple dates might create a false impression of intensified human activity during the period they represent. 2) On the other hand, pooling of all the multiple ${ }^{14} \mathrm{C}$ dates for a single component into 1 averaged, "weighted," or "combined" value, which is then used for calibration and comparison, may result in a misleading conflation and temporal compression of what are really discrete episodes of occupation spanning a long period (Figure 1; see discussion: Kuzmin and Keates 2005:775-7). Here, we illustrate how these 2 difficulties have affected other researchers' conclusions based on the Siberian data.

Surovell et al. (2005), using Kuzmin and Orlova's (1998) data set of Siberian Paleolithic ${ }^{14} \mathrm{C}$ dates, observed that, "Occupation intensities generally increase geometrically through time, with significant declines occurring during the LGM (23-18 ka)" (Surovell et al. 2005:6234). However, using essentially the same database (Kuzmin and Keates 2005; this paper) our conclusion is quite different: no definite decline in occupation intensity occurs at the LGM (Figure 2).

Graf (2005) used the dates listed in another basic source (Vasil'ev et al. 2002), which are very similar to Kuzmin and Orlova's (1998) dates, and concluded that, "In fact, no sites in Siberia can be unequivocally shown to date to between 23,000 and 22,000 CALYPB" (Graf 2005:4). To create her graph of the "number of ${ }^{14} \mathrm{C}$-dated cultural occupations across Siberia," the original ${ }^{14} \mathrm{C}$ dates "were averaged by calculating a weighted mean for each occupation layer. Aberrant dates (that did not overlap other more consistent dates at two sigmas) were not used in the calculations" (Graf 2005:3).

In our research (Kuzmin and Keates 2005; this paper), we have not combined ${ }^{14} \mathrm{C}$ dates and counted only the mean values. Instead, we have assumed that all ${ }^{14} \mathrm{C}$ dates represent episodes of site occupation, and have combined them into $1000-{ }^{14} \mathrm{C}$ yr intervals. This allows use of primary information with less distortion (see example above from the Mal'ta site; Table 1, Figure 1).

According to our results (Figures 2-3), the ostensible gaps in human occupation at 22,000-23,000, $32,000-34,000$, and 39,000-40,000 cal BP (Graf 2005:3, Figure 1) appear to be methodological artifacts. It is impossible to detect 1000 -yr gaps in occupation using ${ }^{14} \mathrm{C}$ dates that have associated standard deviations of up to several hundred years (see Kuzmin and Keates 2005:785 for the original LGM ${ }^{14} \mathrm{C}$ dates from Siberia).

Dolukhanov et al. (2002) and Dolukhanov and Shukurov (2004) also employed averaging of ${ }^{14} \mathrm{C}$ date series, and they concluded that human occupation intensity in Siberia decreased at the LGM. Nevertheless, Dolukhanov (2004:228) has also stated that during the LGM, "the frequencies of sites increased throughout Siberia, including Yakutia and Russian Far East." Dolukhanov's inconsistent interpretation must be clarified before it can be either criticized or defended (see also Kuzmin and Keates 2006).

We suspect that pooling of ${ }^{14} \mathrm{C}$ dates, even from the same cultural "component," may be a procedural mistake. Each ${ }^{14} \mathrm{C}$-dated sample may represent a particular episode of human visitation at the site; people typically came and went repeatedly throughout hundreds or even thousands of years, during each visit leaving behind organic remains with different ${ }^{14} \mathrm{C}$ ages (Kuzmin and Keates 2005: 779-80; see also Table 1 and Figure 1). Therefore, averaging of ${ }^{14} \mathrm{C}$ dates from Paleolithic sites may cause a significant loss of information and create a misleading picture of human occupation inten- 
sity. This can be illustrated using the issue of LGM human presence in Siberia. Previous models of human occupation based on pooling of original ${ }^{14} \mathrm{C}$ data seem to be invalid. As critical evaluation of primary data has shown, people did not disappear from Siberia during the so-called LGM or other cold periods (Kuzmin and Keates 2005:783-5).

\section{CONCLUSION}

Available records do not allow us to establish any straightforward connections between climatic fluctuations and dynamics of human colonization and persistence in the cold region of Siberia in the latter part of the Late Pleistocene, about 36,000-12,000 BP. The frequency of sites and components and inferred density of population in Siberia show no obvious changes in direct response to the rapid temperature fluctuations in the second part of the Late Pleistocene. There is no evidence that very cold climate posed an extraordinary challenge to humans in Siberia, and there is no confirmation for an LGM "hiatus" (whether LGM is defined as about 18,000-19,000 BP [21,000-22,000 cal BP], as about 19,000-20,000 BP [22,000-23,000 cal BP], or as suggested here, about 24,000 cal BP). Population increased rapidly beginning at $\sim 16,000 \mathrm{BP}(19,000 \mathrm{cal} \mathrm{BP})$, prior to significant D-O 1 (Bølling-Allerød) warming, but perhaps in delayed response to increasing summer insolation and the mid-latitude warming trend that may have begun as early as 19,000 cal BP and was widespread by 17,400 cal BP.

\section{ACKNOWLEDGMENTS}

This research was supported by grants from the Russian Foundation for Basic Science (RFFI; Nos. 06-06-80108 and 06-06-80258) and U.S. Fulbright Program (No. 03-27672). We are grateful to 2 anonymous reviewers for useful suggestions.

\section{REFERENCES}

Anikovich MV, Sinitsyn AA, Hoffecker JF, Holliday VT, Popov VV, Lisitsyn SN, Forman SL, Levkovskaya GM, Pospelova GA, Kuz'mina IE, Burova ND, Goldberg P, Macphail RI, Giaccio B, Praslov ND. 2007. Early Upper Paleolithic in Eastern Europe and implications for the dispersal of modern humans. Science 315(5809):223-6.

Behrensmeyer AK. 2006. Climate change and human evolution. Science 311(5760):476-8.

Bender ML, Malaize B, Orchardo J, Sowers T, Jouzel J. 1999. High precision correlations of Greenland and Antarctica over the last 100 kyr. In: Clark P, Webb R, Keigwin L, editors. Mechanisms of Global Climate Change at Millenial Timescales (Geophysical Monograph 112). Washington, D.C.: American Geophysical Union. p 149-64.

Berger A, Loutre MF. 1991. Insolation values for the climate of the last 10 million years. Quaternary Science Reviews 10(4):297-317.

Binford LR. 1982. The archaeology of place. Journal of Anthropological Archaeology 1(1):5-31.

Biscaye PE, Grousset FE, Revel M, van der Gaast S, Zielinski GA, Vaars A, Kukla G. 1997. Asian provenance of glacial dust (stage 2) in the Greenland Ice Sheet Project 2 Ice Core, Summit, Greenland. Journal of Geophysical Research 102(C12):26,765-82.
Bocquet-Appel J-P, Demars P-Y. 2000. Population kinetics in the Upper Palaeolithic in Western Europe. Journal of Archaeological Science 27(7):551-70.

Boës X, Piotrowska N, Fagel N. 2005. High-resolution diatom/clay record in Lake Baikal from grey scale, and magnetic susceptibility over Holocene and Termination I. Global and Planetary Change 46(1-4): 299-313.

Davies W. 2001. A very model of a modern human industry: new perspectives on the origins and spread of the Aurignacian in Europe. Proceedings of the Prehistoric Society 67:195-217.

Derevianko AP. 2001. The Middle to Upper Paleolithic transition in the Altai (Mongolia and Siberia). Archaeology, Ethnology \& Anthropology of Eurasia 2(2)[No. 6]:70-103.

Derevianko AP. 2005. Formation of blade industries in Eastern Asia. Archaeology, Ethnology \& Anthropology of Eurasia 6(4)[No. 24]:2-29.

Dolukhanov PM. 2004. Prehistoric environment, human migrations and origin of pastoralism in northern Eurasia. In: Scott EM, Alekseev AY, Zaitseva GI, editors. Impact of the Environment on Human Migration in Eurasia. Dordrecht: Kluwer Academic Publishers. p 225-42.

Dolukhanov PM, Shukurov A. 2004. Colonization of 
northern Eurasia by early modern humans as viewed through the evidence of radiocarbon dating. In: Higham T, Bronk Ramsey C, Owen C, editors. Radiocarbon and Archaeology (Oxford University School of Archaeology Monograph 62). Oxford: Oxford University School of Archaeology. p 52-61.

Dolukhanov PM, Sokoloff D, Shukurov A. 2001. Radiocarbon chronology of Upper Palaeolithic sites in Eastern Europe at improved resolution. Journal of Archaeological Science 28(7):699-712.

Dolukhanov PM, Shukurov AM, Tarasov PE, Zaitseva GI. 2002. Colonization of northern Eurasia by modern humans: radiocarbon chronology and environment. Journal of Archaeological Science 29(6):593-606.

Dolukhanov PM, Shukurov AM, Tarasov PE, Zaitseva GI. 2005. Reply to Y.V. Kuzmin, S.G. Keates (Journal of Archaeological Science 31 (2004) 141-143). Journal of Archaeological Science 32(7):1125-30.

Gamble C, Davies W, Pettitt P, Richards M. 2004. Climate change and evolving human diversity in Europe during the last glacial. Philosophical Transactions of the Royal Society of London Series B 359(1442):24354.

Gamble C, Davies W, Pettitt P, Hazelwood L, Richards M. 2005. The archaeological and genetic foundations of the European population during the Late Glacial: implications of 'agriculture thinking.' Cambridge Archaeological Journal 15(2):193-223.

Goebel T. 2002. The "microblade adaptation" and recolonization of Siberia during the late Upper Pleistocene. In: Elston RG, Kuhn SL, editors. Thinking Small: Global Perspectives on Microlithization. Arlington, Virginia, USA: American Anthropological Association. p 117-31.

Graf KE. 2005. Abandonment of the Siberian mammothsteppe during the LGM: evidence from the calibration of ${ }^{14} \mathrm{C}$-dated archaeological occupations. Current Research in the Pleistocene 22:2-5.

Hoffecker JF. 2002. Desolate Landscapes: Ice-Age Settlement in Eastern Europe. New Brunswick, New Jersey, USA: Rutgers University Press. 298 p.

Housley RA, Gamble CS, Street M, Pettitt P. 1997. Radiocarbon evidence for the Lateglacial human recolonisation of northern Europe. Proceedings of the Prehistoric Society 63:25-54.

Hubberten HW, Andreev A, Astakhov VI, Demidov I, Dowdeswell JA, Henriksen M, Hjort C, HoumarkNielsen M, Jakobsson M, Kuzmina S, Larsen E, Lunkka JP, Lyså A, Mangerud J, Möller P, Saarnisto M, Schirrmeister L, Sher AV, Siegert C, Siegert MJ, Svendsen JI. 2004. The periglacial climate and environment in northern Eurasia during the Last Glaciation. Quaternary Science Reviews 23(11-13):133357.

Hughen KA, Baillie MGL, Bard E, Beck JW, Bertrand CJH, Blackwell PG, Buck CE, Burr GS, Cutler KB, Damon PE, Edwards RL, Fairbanks RG, Friedrich M, Guilderson TP, Kromer B, McCormac G, Manning S,
Bronk Ramsey C, Reimer PJ, Reimer RW, Remmele S, Southon JR, Stuiver M, Talamo S, Taylor FW, van der Plicht J, Weyhenmeyer CE. 2004. Marine04 radiocarbon age calibration, 0-26 cal kyr BP. Radiocarbon 46(3):1059-86.

Johnsen SJ, Dahl-Jensen D, Gundestrup N, Steffensen JP, Clausen HB, Miller H, Masson-Delmotte V, Sveinbjörnsdottir ÁE, White J. 2001. Oxygen isotope and palaeotemperature records from six Greenland icecore stations: Camp Century, Dye-3, GRIP, GISP2, Renland and NorthGRIP. Journal of Quaternary Science 16(4):299-307.

Kind NV. 1974. Geokhronologiya Pozdnego Antropogena po Izotopnym Dannym [Geochronology of the Late Anthropogene according to isotopic data]. Moscow: Nauka. 255 p. In Russian.

Kuzmin YV, Keates SG. 2005. Dates are not just data: Paleolithic settlement patterns in Siberia derived from radiocarbon records. American Antiquity 70(4):77389.

Kuzmin YV, Keates SG. 2006. Response to "Reply to Y.V. Kuzmin, S.G. Keates (Journal of Archaeological Science 31 (2004) 141-143)" by P.M. Dolukhanov, A.M. Shukurov, P.E. Tarasov, G.I. Zaitseva (Journal of Archaeological Science 32 (2005) 1125-1130). Journal of Archaeological Science 33(6):889-92.

Kuzmin YV, Orlova LA. 1998. Radiocarbon chronology of the Siberian Paleolithic. Journal of World Prehistory 12(1):1-53.

Lagerklint IM, Wright JD. 1999. Late glacial warming prior to Heinrich event 1: the influence of ice rafting and large ice sheets on the timing of initial warming. Geology 27(12):1099-102.

Lipnina EA, Medvedev GI, Oshchepkova EB. 2001. Mal'tinskoe verkhnepaleoliticheskoe mestonakhozhdenie [The Mal'ta Upper Paleolithic locality]. In: Medvedev GI, editor. Kamenny Vek Yuzhnogo Priangarya. Volume 2. Bel'sky Geoarkheologichesky Raion. Irkutsk: Izdatelstvo Irkutskogo Gosudarstvennogo Universiteta. p 46-83. In Russian.

Mellars P. 2006. A new radiocarbon revolution and the dispersal of modern humans in Eurasia. Nature 439(7079):931-5.

Mix AC, Bard E, Schneider R. 2001. Environmental processes of the ice age: land, oceans, glaciers (EPILOG). Quaternary Science Reviews 20(4):627-57.

North Greenland Ice Core Project Members. 2004. Highresolution record of Northern Hemisphere climate extending into the last interglacial period. Nature 431(7005): 147-51.

Peltier WR, Fairbanks RG. 2006. Global glacial ice volume and Last Glacial Maximum duration from an extended Barbados sea level record. Quaternary Science Reviews 25(23-24):3322-37.

Pitulko VV. 2006. Update on Yana RHS. Paper presented at workshop "Pleistocene human colonization of Arctic and Subarctic Siberia and Beringia." Texas A\&M University, College Station, Texas, USA, 17 Novem- 
ber 2006.

Pitulko VV, Nikolsky PA, Girya EY, Basilyan AE, Tumskoy VE, Koulakov SA, Astakhov SN, Pavlova EY, Anisimov MA. 2004. The Yana RHS site: humans in the Arctic before the Last Glacial Maximum. Science 303(5654):52-6.

Prokopenko AA, Karabanov EB, Williams DF, Kuzmin MI, Khursevich GK, Gvozdkov AA. 2001. The detailed record of climatic events during the past 75,000 yrs BP from the Lake Baikal drill core BDP-93-2. Quaternary International 80-81:59-68.

Rinterknecht VR, Clark PU, Raisbeck GM, Yiou F, Bitinas A, Brook EJ, Marks L, Zelčs V, Lunkka J-P, Pavlovskaya IE, Piotrowski JA, Raukas A. 2006. The last deglaciation of the southeastern sector of the Scandinavian ice sheet. Science 311(5766):1449-52.

Schaefer JM, Denton GH, Barrell DJA, Ivy-Ochs S, Kubik PW, Andersen BG, Phillips FM, Lowell TV, Schlüchter C. 2006. Near-synchronous interhemispheric termination of the Last Glacial Maximum in mid-latitudes. Science 312(5779):1510-3.

Shackleton NJ, Fairbanks RG, Chiu T, Parrenin F. 2004. Absolute calibration of the Greenland time scale: implications for Antarctic time scales and for $\Delta^{14} \mathrm{C}$. Quaternary Science Reviews 23(14-15):1513-22.

Southon J. 2004. A radiocarbon perspective on Greenland ice-core chronologies: can we use ice cores for ${ }^{14} \mathrm{C}$ calibration? Radiocarbon $46(3)$ : 1239-59.

Stuiver M, Reimer PJ. 1993. Extended ${ }^{14} \mathrm{C}$ data base and revised CALIB radiocarbon calibration program. $R a-$ diocarbon 35(1):215-30.

Surovell T, Waguespack N, Brantingham PJ. 2005. Global archaeological evidence for proboscidean overkill. Proceedings of the National Academy of Sciences of the USA 102(17):6231-6.

van Andel T, Davies W, editors. 2003. Neanderthals and Modern Humans in the European Landscape During the Last Glaciation: Archaeological Results of the Stage 3 Project. Cambridge: MacDonald Institute for Archaeological Research. 265 p.

van der Plicht J. 2000. Introduction: The 2000 Radiocar- bon Varve/Comparison Issue. Radiocarbon 42(3): 313-22.

van der Plicht J, Beck JW, Bard E, Baillie MGL, Blackwell PG, Buck CE, Friedrich M, Guilderson TP, Hughen KA, Kromer B, McCormac FG, Bronk Ramsey C, Reimer PJ, Reimer RW, Remmele S, Richards DA, Southon JR, Stuiver M, Weyhenmeyer CE. 2004. NotCal04 - comparison/calibration ${ }^{14} \mathrm{C}$ records $26-50$ cal kyr BP. Radiocarbon 46(3): 1225-38.

Vasil'ev SA, Kuzmin YV, Orlova LA, Dementiev VN. 2002. Radiocarbon-based chronology of the Paleolithic of Siberia and its relevance to the peopling of the New World. Radiocarbon 44(2):503-30.

Velichko AA, editor. 1984. Late Quaternary Environments of the Soviet Union. Minneapolis: University of Minnesota Press. 327 p.

Wang YJ, Cheng H, Edwards RL, An ZS, Wu JY, Shen C-C, Dorale JA. 2001. A high-resolution absolutedated Late Pleistocene monsoon record from Hulu Cave, China. Science 294(5550):2345-8.

Weninger B, Jöris O. 2004. Glacial radiocarbon age calibration: the CalPal program. In: Higham T, Bronk Ramsey C, Owen C, editors. Radiocarbon and Archaeology (Oxford University School of Archaeology Monograph 62). Oxford: Oxford University School of Archaeology. p 9-15.

Weninger B, Jöris O. 2006. Use of multi-proxy climate date at the Middle-Upper Palaeolithic boundary. Paper presented at 15th UISPP Congress, Lisbon, Portugal, Session C57 "Setting the Record Straight: Towards a Systematic Understanding of the Middle to Upper Palaeolithic Boundary in Eurasia," 5 September 2006.

Weninger B, Danzeglocke U, Jöris O. 2005. Comparison of dating results achieved using different radiocarbonage calibration curves and data [WWW document]. Available online at http://www.calpal.de/calpal/files/ CalCurveComparisons.pdf.

Yokoyama Y, Lambeck K, de Deckker P, Johnston P, Fifield LK. 2000. Timing of the Last Glacial Maximum from observed sea-level minima. Nature 406(6797):713-6.

\section{APPENDIX}

Table The occupations' mean ${ }^{14} \mathrm{C}$ ages and "calibrated" ages of their median points (centroids) for Paleolithic sites in Siberia, about 12,000-35,800 BP (original ${ }^{14} \mathrm{C}$ dates are after Vasil'ev et al. 2002; Kuzmin and Keates 2005). 1. = layer(s).

\begin{tabular}{|c|c|c|c|c|c|c|c|}
\hline Site name and layer $\mathrm{nr}$ & $\begin{array}{l}\text { Average } \\
{ }^{14} \mathrm{C} \text { age, } \\
\text { uncalib BP }\end{array}$ & $\begin{array}{l}\mathrm{Nr} \text { of }{ }^{14} \mathrm{C} \\
\text { dates } \\
\text { used }\end{array}$ & $\begin{array}{l}\text { Median } \\
\text { point, } \\
\text { cal BP }\end{array}$ & Site name and layer nr & $\begin{array}{l}\text { Average } \\
{ }^{14} \mathrm{C} \text { age, } \\
\text { uncalib BP }\end{array}$ & $\begin{array}{l}\mathrm{Nr} \text { of }{ }^{14} \mathrm{C} \\
\text { dates } \\
\text { used }\end{array}$ & $\begin{array}{l}\text { Median } \\
\text { point, } \\
\text { cal BP }\end{array}$ \\
\hline $\begin{array}{l}\text { Strizhovaya Gora, } \\
\text { l. } 16-14\end{array}$ & 12,115 & 3 & 14,510 & Shestakovo, 1. 17 & 19,190 & 1 & 22,800 \\
\hline Bolshoi Yakor, 1. 3v & 12,390 & 13 & 14,770 & Ui $1,1.2$ & 19,280 & 1 & 22,900 \\
\hline Malye Kuruktachi & 12,250 & 2 & 14,630 & Ogonki 5, 1. 2b & 19,380 & 2 & 23,010 \\
\hline Eleneva Cave & 12,050 & 4 & 14,470 & Ust-Ulma $1,1.2$ & 19,360 & 1 & 22,990 \\
\hline Sosnovy Bor, 1. 3b & 12,080 & 2 & 14,490 & $\begin{array}{l}\text { Ust-Kova, lower } \\
\text { component }\end{array}$ & 19,540 & 1 & 23,190 \\
\hline
\end{tabular}


Table The occupations' mean ${ }^{14} \mathrm{C}$ ages and "calibrated" ages of their median points (centroids) for Paleolithic sites in Siberia, about 12,000-35,800 BP (original ${ }^{14} \mathrm{C}$ dates are after Vasil'ev et al. 2002; Kuzmin and Keates 2005). 1. = layer(s). (Continued)

\begin{tabular}{|c|c|c|c|c|c|c|c|}
\hline Site name and layer nr & $\begin{array}{l}\text { Average } \\
{ }^{14} \mathrm{C} \text { age, } \\
\text { uncalib BP }\end{array}$ & $\begin{array}{l}\mathrm{Nr} \text { of }{ }^{14} \mathrm{C} \\
\text { dates } \\
\text { used }\end{array}$ & $\begin{array}{l}\text { Median } \\
\text { point, } \\
\text { cal BP }\end{array}$ & Site name and layer $\mathrm{nr}$ & $\begin{array}{l}\text { Average } \\
{ }^{14} \mathrm{C} \text { age, } \\
\text { uncalib BP }\end{array}$ & $\begin{array}{l}\mathrm{Nr} \text { of }{ }^{14} \mathrm{C} \\
\text { dates } \\
\text { used }\end{array}$ & $\begin{array}{l}\text { Median } \\
\text { point, } \\
\text { cal BP }\end{array}$ \\
\hline $\begin{array}{l}\text { Kosaya Shivera } 1, \\
\text { 1. } 14\end{array}$ & 12,070 & 1 & 14,480 & Ikhine 2 & 19,695 & 1 & 23,490 \\
\hline Kokorevo 2 & 12,090 & 1 & 14,490 & Mal'ta, 1. 8 & 19,890 & 2 & 23,800 \\
\hline Ust-Kyakhta $17,1.5$ & 12,170 & 2 & 14,600 & Tesa & 20,040 & 1 & 23,940 \\
\hline Dyuktai Cave, 1. 7a & 12,530 & 3 & 14,840 & Studenoe 2 & 20,620 & 1 & 24,600 \\
\hline Mayiniskaya & 12,310 & 6 & 14,640 & Ikhine 2 & 20,080 & 1 & 23,980 \\
\hline Studenoe 1 & 12,300 & 7 & 14,640 & Mogochino 1 & 20,150 & 1 & 24,070 \\
\hline Goly Mys 4 & 12,645 & 4 & 14,970 & Malaya Syia & 20,300 & 1 & 24,330 \\
\hline Mal'ta & 12,315 & 2 & 14,650 & Mal'ta, 1.8 & 20,730 & 5 & 24,700 \\
\hline $\begin{array}{l}\text { Kaminnaya Cave, } \\
1.11 \mathrm{v}\end{array}$ & 12,160 & 1 & 14,600 & Anyi $2,1.8$ & 20,350 & 1 & 24,380 \\
\hline Tashtyk 1, 1. 1 & 12,530 & 2 & 14,840 & Shestakovo, 1. 19 & 20,580 & 5 & 24,570 \\
\hline Ust-Mil 2, 1. 3 & 12,200 & 1 & 14,620 & Kashtanka 1 & 20,800 & 1 & 24,800 \\
\hline $\begin{array}{l}\text { Nizhniaya Dzhilinda } 1 \text {, } \\
\text { 1. } 7\end{array}$ & 12,330 & 1 & 14,760 & Mal'ta, 1.8 & 21,420 & 7 & 25,600 \\
\hline Volchiya Griva & 12,520 & 1 & 14,830 & Kunalei & 21,100 & 1 & 25,320 \\
\hline $\begin{array}{l}\text { Verkholenskaya Gora } \\
1,1.3 \mathrm{~d}\end{array}$ & 12,570 & 1 & 14,890 & Buret' & 21,190 & 1 & 25,410 \\
\hline Ust'-Kyakhta 4, 1. 2 & 12,595 & 1 & 14,910 & Shishkino 8 & 21,190 & 1 & 25,410 \\
\hline Kokorevo 3 & 12,690 & 1 & 15,000 & Igeteisky $\log 1,1.4$ & 21,260 & 1 & 25,470 \\
\hline Ust-Karenga $12,1.8$ & 12,800 & 2 & 15,110 & Anyi $2,1.3-4$ & 21,390 & 2 & 25,580 \\
\hline Avdeikha & 12,900 & 1 & 15,210 & Shestakovo, 1. 17, 21 & 21,430 & 2 & 25,610 \\
\hline Tyitkesken' 3, 1. 6 & 12,850 & 1 & 15,150 & Kashtanka 1 & 21,800 & 1 & 26,400 \\
\hline Golubaya $1,1.3$ & 12,940 & 2 & 15,250 & Novoselovo $13,1.3$ & 22,000 & 1 & 26,600 \\
\hline Bolshaya Slizneva, 1. 7 & 12,930 & 1 & 15,240 & Shestakovo & 22,580 & 6 & 27,280 \\
\hline Berelekh & 12,930 & 1 & 15,240 & Alexeevsk 1 & 22,415 & 1 & 26,940 \\
\hline Kokorevo 1, 1. 2-3 & 12,970 & 2 & 15,290 & Khodulikha & 22,530 & 1 & 27,080 \\
\hline Golubaya $1,1.3$ & 13,350 & 2 & 15,900 & Dvuglazka & 22,500 & 1 & 27,040 \\
\hline Dyuktai Cave, 1.7 & 13,350 & 4 & 15,900 & Anyi $2,1.8$ & 22,610 & 1 & 27,370 \\
\hline Listvenka, 1. 12-6 & 13,510 & 3 & 16,240 & Podzvonkaya & 22,675 & 1 & 27,490 \\
\hline Kokorevo 1, 1. 2-3 & 13,200 & 2 & 15,660 & Ui $1,1.2$ & 22,830 & 1 & 27,680 \\
\hline Kurla 3,1.1 & 13,160 & 1 & 15,600 & Sabanikha & 22,915 & 2 & 27,760 \\
\hline Divnyi 1 & 13,220 & 1 & 15,690 & Arta $2,1.3$ & 23,200 & 1 & 27,800 \\
\hline Siberdik, 1.3 & 13,225 & 1 & 15,700 & Shestakovo, 1. 19, 22 & 23,290 & 3 & 28,070 \\
\hline Lugovskoe & 13,465 & 1 & 16,130 & Anyi $2,1.6$ & 23,430 & 1 & 28,210 \\
\hline Kaminnaya Cave & 13,800 & 4 & 16,570 & Kurtak 4, 1. 11 & 23,760 & 3 & 28,690 \\
\hline Kokorevo 2 & 13,300 & 1 & 15,820 & Biika 1, 1. 5 & 23,480 & 1 & 28,280 \\
\hline Malye Kuruktachi & 13,560 & 2 & 16,300 & $\begin{array}{l}\text { Ust-Mil 2, } 1.4 \\
\text { (upper part) }\end{array}$ & 23,500 & 1 & 28,310 \\
\hline Afontova Gora 2, 1. 2-4 & 13,610 & 6 & 16,350 & Igeteisky $\log 1,1.4$ & 23,640 & 2 & 28,530 \\
\hline Berelekh & 13,420 & 1 & 16,030 & $\begin{array}{l}\text { Ust-Kova, middle } \\
\text { component }\end{array}$ & 23,920 & 1 & 28,850 \\
\hline Studenoe 1, 1. 18/1 & 13,430 & 1 & 16,050 & Kurtak 4, 1. 11 & 24,620 & 3 & 29,680 \\
\hline Bolshaya Slizneva, 1. 8 & 13,540 & 1 & 16,280 & Anyi $2,1.8$ & 24,205 & 1 & 29,080 \\
\hline Tashtyk 2, 1. 2 & 13,550 & 1 & 16,290 & Ikhine $2,1.2 \mathrm{~b}$ & 24,480 & 3 & 29,480 \\
\hline Ust-Karenga $12,1.8$ & 13,560 & 1 & 16,300 & Shestakovo, 1. 19, 24 & 24,480 & 2 & 29,480 \\
\hline
\end{tabular}


Table The occupations' mean ${ }^{14} \mathrm{C}$ ages and "calibrated" ages of their median points (centroids) for Paleolithic sites in Siberia, about 12,000-35,800 BP (original ${ }^{14} \mathrm{C}$ dates are after Vasil'ev et al. 2002; Kuzmin and Keates 2005). l. = layer(s). (Continued)

\begin{tabular}{|c|c|c|c|c|c|c|c|}
\hline Site name and layer $\mathrm{nr}$ & $\begin{array}{l}\text { Average } \\
{ }^{14} \mathrm{C} \text { age, } \\
\text { uncalib BP }\end{array}$ & $\begin{array}{l}\text { Nr of }{ }^{14} \mathrm{C} \\
\text { dates } \\
\text { used }\end{array}$ & $\begin{array}{l}\text { Median } \\
\text { point, } \\
\text { cal BP }\end{array}$ & Site name and layer $\mathrm{nr}$ & $\begin{array}{l}\text { Average } \\
{ }^{14} \mathrm{C} \text { age, } \\
\text { uncalib BP }\end{array}$ & $\begin{array}{l}\mathrm{Nr} \text { of }{ }^{14} \mathrm{C} \\
\text { dates } \\
\text { used }\end{array}$ & $\begin{array}{l}\text { Median } \\
\text { point, } \\
\text { cal BP }\end{array}$ \\
\hline Novoselovo 6 & 13,570 & 1 & 16,310 & Masterov Kliych, 1. 4 & 24,360 & 1 & 29,310 \\
\hline Volchiya Griva & 13,600 & 2 & 16,340 & Igeteisky $\log 1,1.6$ & 24,400 & 1 & 29,360 \\
\hline Ushki $1,1.7$ & 13,700 & 2 & 16,460 & Kamenka 1 & 24,625 & 1 & 29,700 \\
\hline Novoselovo $13,1.1$ & 13,630 & 1 & 16,380 & Kashtanka 1 & 24,805 & 1 & 29,840 \\
\hline $\begin{array}{l}\text { Eleneva Cave, } \\
\text { section } 1\end{array}$ & 13,665 & 1 & 16,420 & Yana RHS & 25,800 & 1 & 30,670 \\
\hline Mayiniskaya, 1. 3-4 & 13,800 & 2 & 16,570 & Balyshevo 3, 1. 2 & 25,100 & 1 & 30,050 \\
\hline Biruisa $1,1.4$ & 13,840 & 1 & 16,620 & Tolbaga, 1. 4 & 25,200 & 1 & 30,160 \\
\hline $\begin{array}{l}\text { Ust-Kova, middle } \\
\text { component }\end{array}$ & 13,860 & 1 & 16,640 & Malaya Syia & 25,250 & 1 & 30,230 \\
\hline Shishkino $2,1.3$ & 13,900 & 1 & 16,690 & Sabanikha & 25,440 & 1 & 30,460 \\
\hline Strizhovaya Gora, 1.18 & 14,000 & 1 & 16,810 & Kamenka 1 & 25,540 & 1 & 30,520 \\
\hline Afontova Gora 2 & 14,195 & 4 & 17,030 & Kara-Tenesh & 25,630 & 1 & 30,580 \\
\hline Mayiniskaya, 1.3 & 14,070 & 1 & 16,890 & Shestakovo, 1. 24 & 25,660 & 1 & 30,590 \\
\hline Studenoe 2 & 14,485 & 1 & 17,370 & $\begin{array}{l}\text { Mal'ta, contact } 1.7 \\
\text { and } 3\end{array}$ & 25,760 & 1 & 30,650 \\
\hline Oznachennoye 1 & 14,100 & 1 & 16,920 & Priiskovaya & 25,825 & 1 & 30,680 \\
\hline $\begin{array}{l}\text { Kaminnaya Cave, } \\
\text { l. 13-14a }\end{array}$ & 14,340 & 2 & 17,200 & Podzvonkaya & 26,000 & 1 & 30,780 \\
\hline Kurla 6 & 14,150 & 1 & 16,980 & Nepa & 26,100 & 1 & 30,840 \\
\hline Listvenka, 1. 7-9 & 14,460 & 2 & 17,340 & Sokhatino 4 & 26,110 & 1 & 30,850 \\
\hline Volchiya Griva & 14,240 & 2 & 17,080 & Khotyk 3, 1. 2 & 26,220 & 1 & 30,920 \\
\hline Biruisa $1,1.4$ & 14,520 & 4 & 17,410 & Ust-Karakol 1, 1. 4-5 & 26,715 & 3 & 31,180 \\
\hline Malye Kuruktachi & 14,200 & 1 & 17,040 & Dvuglazka, 1.4 & 26,580 & 1 & 31,120 \\
\hline Novoselovo 7 & 14,610 & 2 & 17,510 & Kamenka 1 & 26,760 & 1 & 31,200 \\
\hline $\begin{array}{l}\text { Ust-Kova, upper } \\
\text { component }\end{array}$ & 14,220 & 1 & 17,060 & Anyi $2,1.12$ & 26,810 & 1 & 31,220 \\
\hline Kurtak 3 & 14,430 & 3 & 17,300 & Kara-Tenesh & 26,875 & 1 & 31,250 \\
\hline Ushki $1,1.7$ & 14,300 & 1 & 17,150 & Tolbaga, 1.4 & 26,900 & 1 & 31,260 \\
\hline Ui $2,1.6$ & 14,310 & 1 & 17,160 & Yana RHS & 27,535 & 4 & 31,860 \\
\hline Kokorevo 4A, 1. 5-3 & 14,320 & 1 & 17,180 & Ust-Karakol 1, 1.5 & 27,020 & 1 & 31,310 \\
\hline Kokorevo 1, 1. 3 & 14,450 & 1 & 17,330 & Anyi $2,1.9,12$ & 27,530 & 2 & 31,860 \\
\hline Chernoozierye 2, 1. 3-2 & 14,500 & 1 & 17,380 & Dvuglazka Cave & 27,200 & 1 & 31,420 \\
\hline Tashtyk 4 & 14,700 & 1 & 17,620 & Tolbaga, 1.4 & 27,210 & 1 & 31,430 \\
\hline Mal'ta & 14,740 & 2 & 17,660 & Kurtak 4, 1. 12-11 & 27,470 & 1 & 31,750 \\
\hline Dmitrievka, 1. 4-3 & 14,750 & 1 & 17,670 & Yana RHS & 28,250 & 1 & 32,780 \\
\hline Ust-Menza 2, 1. 11 & 14,830 & 1 & 17,770 & $\begin{array}{l}\text { Ust-Kova, lower } \\
\text { component }\end{array}$ & 28,050 & 1 & 32,520 \\
\hline Studenoe $1,1.15$ & 14,900 & 1 & 17,850 & Kamenka 1 & 28,440 & 2 & 33,090 \\
\hline Oznachennoye 1 & 15,020 & 1 & 17,990 & Okladnikov Cave, l. 1 & 28,470 & 1 & 33,150 \\
\hline Novoselovo 13, 1. 1 & 15,030 & 1 & 18,000 & Ust-Karakol 1 & 28,700 & 1 & 33,720 \\
\hline Tolbaga, 1. 3 & 15,100 & 1 & 18,080 & Denisova Cave & 29,200 & 1 & 34,460 \\
\hline Suvorovo 4 & 15,410 & 4 & 18,440 & Masterov Kliych & 29,860 & 1 & 35,190 \\
\hline Afontova Gora 2, 1.5 & 15,130 & 1 & 18,110 & Tolbaga, 1.4 & 29,200 & 1 & 34,460 \\
\hline Kokorevo 1, 1. 2-3 & 15,550 & 2 & 18,600 & Derbina 5 & 29,230 & 1 & 34,490 \\
\hline Mayiniskaya & 15,350 & 2 & 18,370 & Malaya Syia & 29,450 & 1 & 34,720 \\
\hline
\end{tabular}


Table The occupations' mean ${ }^{14} \mathrm{C}$ ages and "calibrated" ages of their median points (centroids) for Paleolithic sites in Siberia, about 12,000-35,800 BP (original ${ }^{14} \mathrm{C}$ dates are after Vasil'ev et al. 2002; Kuzmin and Keates 2005). $1 .=$ layer(s). (Continued)

\begin{tabular}{|c|c|c|c|c|c|c|c|}
\hline Site name and layer $\mathrm{nr}$ & $\begin{array}{l}\text { Average } \\
{ }^{14} \mathrm{C} \text { age, } \\
\text { uncalib BP }\end{array}$ & $\begin{array}{l}\mathrm{Nr} \text { of }{ }^{14} \mathrm{C} \\
\text { dates } \\
\text { used }\end{array}$ & $\begin{array}{l}\text { Median } \\
\text { point, } \\
\text { cal BP }\end{array}$ & Site name and layer $\mathrm{nr}$ & $\begin{array}{l}\text { Average } \\
{ }^{14} \mathrm{C} \text { age, } \\
\text { uncalib BP }\end{array}$ & $\begin{array}{l}\mathrm{Nr} \text { of }{ }^{14} \mathrm{C} \\
\text { dates } \\
\text { used }\end{array}$ & $\begin{array}{l}\text { Median } \\
\text { point, } \\
\text { cal BP }\end{array}$ \\
\hline Kurla 3, 1. 1 & 15,200 & 1 & 18,200 & Voenny Gospital & 29,700 & 1 & 35,000 \\
\hline Avdeikha & 15,200 & 1 & 18,200 & Ust-Karakol 1 & 29,830 & 3 & 35,160 \\
\hline Berezovyi Ruchei 1 & 15,310 & 1 & 18,320 & Varvarina Gora, 1.2 & 29,895 & 1 & 35,230 \\
\hline Anyi 2 & 15,350 & 1 & 18,370 & $\begin{array}{l}\text { Ust-Kova, lower } \\
\text { component }\end{array}$ & 30,100 & 1 & 35,420 \\
\hline Ust-Menza 2, 1. 17 & 15,400 & 1 & 18,430 & Kamenka 1 & 30,340 & 2 & 35,590 \\
\hline Kokorevo 4B & 15,480 & 1 & 18,520 & Mokhovo 2 & 30,330 & 1 & 35,580 \\
\hline Pritubinsk, 1. 3 & 15,600 & 1 & 18,660 & Ust-Karakol 1, 1.5 & 30,460 & 1 & 35,660 \\
\hline Ikhine 2 & 15,780 & 1 & 18,660 & Varvarina Gora & 30,600 & 1 & 35,770 \\
\hline Sokhatino $4,1.6$ & 15,820 & 1 & 18,910 & Kara-Bom, 1. 2d & 30,990 & 1 & 36,130 \\
\hline Bolshoi Yakor, 1.6 & 15,900 & 1 & 19,000 & Kamenka 1 & 31,060 & 1 & 36,190 \\
\hline Novoselovo 7 & 15,950 & 1 & 19,050 & Makarovo 3 & 31,200 & 1 & 36,290 \\
\hline Khaergas Cave, 1.6 & 16,000 & 1 & 19,110 & Ust-Karakol 1 & 31,400 & 3 & 36,420 \\
\hline Mayiniskaya, 1. 5 & 16,360 & 2 & 19,520 & Kara-Tenesh & 31,400 & 1 & 36,420 \\
\hline Listvenka, 1.19 & 16,470 & 2 & 19,650 & Mamony $2,1.4$ & 31,400 & 1 & 36,420 \\
\hline Studenoe 2 & 16,580 & 2 & 19,770 & Strashnaya Cave & 31,510 & 1 & 36,510 \\
\hline Khodulikha & 16,480 & 1 & 19,660 & Kurtak 4, 1. 17 & 31,850 & 1 & 36,800 \\
\hline Ust-Karenga $12,1.8$ & 16,430 & 1 & 19,600 & Masterov Kliych & 32,510 & 1 & 37,930 \\
\hline Ikhine $1,1.2$ & 16,660 & 1 & 19,860 & Kara-Bom, 1. 4-3 & 32,200 & 1 & 37,600 \\
\hline Ui $1,1.2$ & 16,760 & 1 & 19,980 & Kurtak 4, 1. 17 & 32,280 & 1 & 37,750 \\
\hline Sokhatino $4,1.7-8$ & 16,900 & 2 & 20,140 & $\begin{array}{l}\text { Okladnikov Cave, } \\
1.2-3\end{array}$ & 32,580 & 2 & 37,970 \\
\hline Kurtak 3 & 16,900 & 1 & 20,140 & Derbina 5 & 32,430 & 1 & 37,870 \\
\hline Ust-Menza 2, 1. 17, 20 & 16,940 & 2 & 20,180 & $\begin{array}{l}\text { Geographical Society } \\
\text { Cave }\end{array}$ & 32,570 & 1 & 37,960 \\
\hline Varvarina Gora, 1.1 & 17,035 & 1 & 20,290 & Nepa & 33,100 & 1 & 38,210 \\
\hline Ezhantsy, 1. 3 & 17,150 & 1 & 20,430 & $\begin{array}{l}\text { Malyi Yaloman Cave, } \\
\text { 1. } 3\end{array}$ & 33,350 & 1 & 38,330 \\
\hline Studenoe 2 & 17,630 & 4 & 20,980 & Ust-Karakol $1,1.9 \mathrm{v}$ & 33,400 & 1 & 38,360 \\
\hline Ust-Menza 2 & 17,400 & 2 & 20,710 & Okladnikov Cave, 1.1 & 33,500 & 1 & 38,440 \\
\hline Nizhny Idzhir 1 & 17,200 & 1 & 20,480 & Aryshevskoe 1, 1.6 & 33,630 & 1 & 38,810 \\
\hline Ui $1,1.2$ & 17,520 & 1 & 20,850 & Kara-Bom, 1. 2c, 4 & 33,790 & 2 & 40,000 \\
\hline Bolshoi Yakor, 1. 5 & 17,840 & 1 & 21,220 & Kara-Bom, 1. 4 & 34,180 & 1 & 40,280 \\
\hline Ogonki $5,1.2 b$ & 17,860 & 1 & 21,240 & $\begin{array}{l}\text { Ust-Kova, lower } \\
\text { component }\end{array}$ & 34,300 & 1 & 40,330 \\
\hline Mamakan & 18,670 & 1 & 22,190 & $\begin{array}{l}\text { Geographical Society } \\
\text { Cave }\end{array}$ & 34,400 & 3 & 40,370 \\
\hline Ust-Kova & 18,035 & 1 & 21,450 & Malaya Syia & 34,460 & 2 & 40,390 \\
\hline Shestakovo, 1. 17 & 18,040 & 1 & 21,450 & Kara-Tenesh & 34,760 & 1 & 40,540 \\
\hline Shikaevka & 18,050 & 1 & 21,470 & Tolbaga, 1.4 & 34,860 & 1 & 40,600 \\
\hline Novoselovo 6 & 18,090 & 1 & 21,510 & Varvarina Gora & 34,900 & 1 & 40,620 \\
\hline Tomsk & 18,300 & 1 & 21,760 & Ust-Karakol 1, 1. 10 & 35,100 & 1 & 40,740 \\
\hline $\begin{array}{l}\text { Verkhne-Troitskaya, } \\
\text { l. } 6\end{array}$ & 18,300 & 1 & 21,760 & $\begin{array}{l}\text { Geographical Society } \\
\text { Cave }\end{array}$ & 35,100 & 1 & 40,740 \\
\hline Studenoe $1,1.19 / 4$ & 18,550 & 1 & 22,050 & Denisova Cave, 1.21 & 35,140 & 1 & 40,770 \\
\hline Ogonki 5, 1. 2b & 18,920 & 1 & 22,480 & Kamenka 1 & 35,845 & 1 & 41,750 \\
\hline Krasny Yar 1, 1. 6 & 19,100 & 1 & 22,690 & & & & \\
\hline
\end{tabular}

